\title{
Revision of Kadua (Rubiaceae) in the Marquesas Islands, French Polynesia, with description of the new species $K$. lichtlei
}

\author{
David H. Lorence', Warren L. Wagner ${ }^{2}$ \\ I National Tropical Botanical Garden, 3530 Papalina Road, Kalaheo, HI 96741, USA 2 Department of \\ Botany, MRC-166, Smithsonian Institution, P. O. Box 37012, Washington, DC 20013-7012, USA \\ Corresponding author: David H. Lorence (lorence@ntbg.org)
}

Academic editor: Vicki Funk | Received 26 May 2011 | Accepted 15 June 2011 | Published 12 July 2011

Citation: Lorence DH, Wagner WL (2011) Revision of Kadua (Rubiaceae) in the Marquesas Islands, French Polynesia, with description of the new species K. lichtlei. In: Lorence DH, Wagner WL (Eds) Botany of the Marquesas Islands: new taxa, combinations, and revisions. PhytoKeys 4: 125-138. doi: 10.3897/phytokeys.4.1601

\begin{abstract}
Kadua lichtlei Lorence \& W. L. Wagner, sp. nov., a new species from Ua Huka, Marquesas Islands, is described and illustrated. This new species differs from the three other Marquesan Kadua species by its broadly elliptic to broadly ovate or subcircular leaf blades as well as much smaller and more numerous (80300) flowers and smaller capsules. Known from a single population of about 30 individuals, we conclude this new species should be added to the IUCN Red List as critically endangered (CR). A key, amended descriptions, conservation status, and specimen citations for the three previously described Marquesan species, Kadua lucei, K. nukuhivensis, and K. tahuatensis are also provided.
\end{abstract}

\section{Keywords}

Conservation, French Polynesia, Kadua, Marquesas Islands, Rubiaceae

\section{Introduction}

Until recently the Marquesas Islands were relatively poorly explored botanically. Prior to initiation of the Flore de la Polynésie française project under the auspices of Jacques Florence at IRD (formerly ORSTOM) no species of Rubiaceae belonging to tribe Spermacoceae were known from these islands (Brown 1935). Collecting there intensi- 
fied greatly with the onset of this project, and Florence and collaborators discovered two distinctive woody species of Kadua Cham. \& Schltdl. One additional related species was discovered during the collecting phase of the current Vascular Flora of the Marquesas Islands project under the direction of David H. Lorence and Warren L. Wagner (Wagner and Lorence 1997; see website at http://botany.si.edu/pacificislandbiodiversity/marquesasflora/index.htm). These new taxa were published as Hedyotis lucei, $H$. nukuhivensis, and H. tahuatensis by Florence and Lorence (2000). Additional field work in 2003-2004 revealed the presence of yet another species on Ua Huka apparently not closely related to the other three which is described below.

Generic delimitations in Hedyotis L. and related genera in Hedyotidinae have not been fully resolved, although recent morphological and molecular studies suggest that Hedyotis s. str. is an Old World genus ranging from southeastern Asia to the Caroline Islands of Micronesia and with two widespread species ranging into western Polynesia (Church 2003; Terrell and Robinson 2003; Kårehed et al. 2008; Groeninckx et al. 2009). Virtually all the Polynesian species, the majority Hawaiian, were formerly placed in Hedyotis (Fosberg 1943; Wagner et al. 1990). However, results from a recent study of Hawaiian species of Kadua, focusing on capsule and seed morphology, revealed that these characters of Hawaiian and certain South Pacific species are distinct from other Asian and western Pacific species of Hedyotis, and consequently they have been transferred to the genus Kadua (Terrell et al. 2005). Kadua now comprises some 30 species including this new species and $K$. haupuensis Lorence \& W. L. Wagner, a new species recently described from Kaua $i$ (Lorence et al. 2010).

Based on their salverform, fleshy corollas with appendaged lobes and non-diplophragmous capsules (i.e., that do not separate into paired cocci after dehiscing), the three Marquesan species formerly placed in the genus Hedyotis (Florence $\&$ Lorence 2000) have been transferred to the genus Kadua by Terrell et al. (2005). These include Kadua lucei (Lorence \& J. Florence) Lorence \& W. L. Wagner, K. nukubivensis (J. Florence \& Lorence) Lorence \& W. L. Wagner, and K. tahuatensis (Lorence \& J. Florence) Lorence \& W. L. Wagner.

Results of an unpublished molecular analysis (Motley 2003) place species of the Hawaiian Kadua sect. Kadua in the same clade as sect. Protokadua with a single Hawaiian species, sect. Gouldiopsis with four Hawaiian species, and sect. Austrogouldia with six species including two Marquesan species (only K. nukuhivensis and K. tahuatensis were examined), two from the Society Islands, and $K$. rapensis $F$. Br. from Rapa, as well as the unispecific sect. Oceanica with a single species, $K$. romanzoffiansis Cham. \& Schltdl. from southeastern Polynesia. Together these taxa constitute the large Hawaiian and French Polynesian clade (Motley 2003).

\section{Methodology}

All measurements given herein are taken from dried herbarium specimens, although certain features such as shapes were supplemented with information from alcohol-pre- 
served flowers and fruits, field notes, and digital photos. Measurements are presented in the descriptions as follows: length $\times$ width, followed by units of measurement $(\mathrm{mm}$ or $\mathrm{cm}$ ). All specimens cited in this paper have been seen by the authors. Specimens from the following herbaria were studied: AD, BISH, BR, K, MO, NY, P, PAP, PTBG, and US. The area of occupancy (distribution) for this species was calculated using herbarium collection data and field observations, and the conservation status is proposed following the IUCN Red List Category criteria (IUCN 2001; www.iucnredlist.org/ info/categories_criteria2001).

\section{Systematics}

\section{Key to species of Kadua in the Marquesas Islands}

1a Inflorescences with 80-300 flowers; corolla tube 1.8-2.2 mm long; capsules 4-5 mm long, 3.5-4 mm wide; seeds 0.5-0.6 mm long, 0.35-0.4 mm wide, irregularly ovoid to ellipsoid. K. lichtlei

1b Inflorescences with 12-30 flowers; corolla tube 13-28 mm long; capsules 7-22 mm long, 6-12 mm wide; seeds 0.9-1.3 mm long, irregularly trigonous or angulate (unknown in $K$. lucei) 2

2a Inflorescences 3-6 cm long; corolla tube 13-16 mm long; Tahuata

K. tabuatensis

2b Inflorescences 8-13 cm long; corolla tube 22-28 mm long; Nuku Hiva; Fatu Hiva......................................................................................... 3

3a Corolla lobes 8-10 mm long; capsules 7-8 $\mathrm{mm}$ long, $6 \mathrm{~mm}$ wide; Fatu Hiva. K. lucei

3b Corolla lobes 10-15 mm long; capsules 15-22 mm long, 7-12 mm wide; Nuku Hiva

K. nukubivensis

\section{Kadua lichtlei Lorence \& W.L.Wagner, sp. nov.}

urn:1sid:ipni.org:names:77112739-1

http://species-id.net/wiki/Kadua_lichtlei

Figs. 1, 2A,B, 3

Differt a congeneribus Marquesanis laminis late ovatis vel late ellipticis vel rotundis (3-) 5-17.5 × (1.8-) 3.5-11.5 cm, inflorescentia 6.5-14 ×9-12 cm, floribus in inflorescentibus 80-300, parvis, hypanthio 1-1.8 mm longo, corollae tubo 1.8-2.2 $\mathrm{mm}$ longo, corollae lobis 1.5-2 mm longis, et capsulis minoribus 4-5 $\times 3.5-4 \mathrm{~mm}$.

Type. Marquesas Islands: Ua Huka: Hane/Hokatu cliff zone, 520m elevation, 14 December 2003, K.R Wood and J.-Y. Meyer 10554 (holotype PTBG-44091!; Isotypes AD!, BISH!, BR!, K!, MO!, NY!, P!, PAP!, US!). 


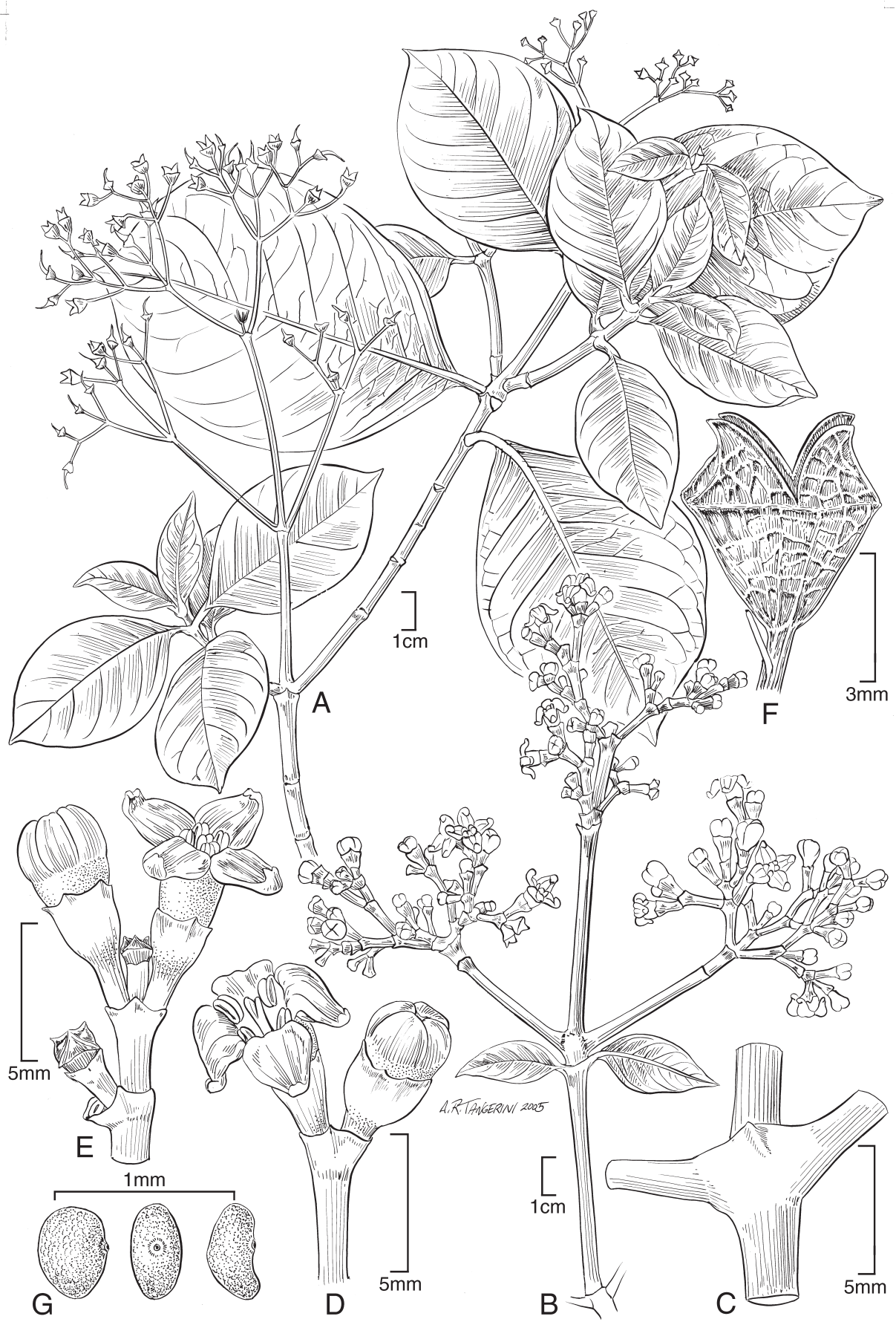

Figure I. Kadua lichtlei Lorence \& WL Wagner A habit, fruiting branch B inflorescence $\mathbf{C}$ node showing stipule and petiole bases $\mathbf{D}, \mathbf{E}$ flowers in bud and at anthesis $\mathbf{F}$ mature capsule, dehisced $\mathbf{G}$ seeds, lateral and dorsal (center) views. A, F, G. based on the type collection Wood \& Meyer 10554; B, C, D, E based on Lorence 9476. 
Description. Shrub or small tree reaching $4 \mathrm{~m}$ tall, glabrous except for inflorescence, moderately branched, branches diffuse or often decumbent, twigs 3-3.5 mm in diam., internodes compressed, bark smooth to striate, dark brown. Leaves opposite, those of a pair at a node equal or sometimes unequal, blade (3-) 5-17.5 × (1.8-) $3.5-11.5 \mathrm{~cm}$, broadly ovate, broadly elliptic, broadly obovate-elliptic or subcircular, chartaceous, glabrous, when fresh glossy dark green above, light green beneath, costa greenish white, margins entire, base acute to obtuse or rounded, shortly decurrent, apex obtuse or rounded, tip abruptly short acuminate, $0.5-1.5 \mathrm{~cm}$, secondary veins $6-9(-11)$ per side, festooned brochidodromous, venation prominulous and conspicuous to $3^{\circ}$ adaxially and to $4^{\circ}$ abaxially; petioles (0.5-) 1-2 cm long, winged distally; stipules interpetiolar (occasionally also intrapetiolar), fused with adaxial petiole bases, the body forming a short, broadly triangular sheath $1.5-3 \times 3-7 \mathrm{~mm}$, apiculate or with a short lateral ridge, glabrous, persistent. Inflorescences terminal, 6.5-14 ×9-12 cm (including the corollas), cymose-paniculate or -corymbiform, trichotomous, 80-300-flowered, sessile or sometimes with peduncle $3-4 \mathrm{~cm}$ long, the basal primary branches subtended by a pair of short petiolate, ovate foliaceous bracts $2-3.5 \mathrm{~cm}$ long, branching to the $4^{\circ}\left(-5^{\circ}\right)$, axes and pedicels minutely papillose-puberulent, subtended by brown triangular acuminate bracts $0.5-2 \times 0.5-1 \mathrm{~mm}$. Flowers hermaphroditic, apparently monomorphic and protandrous, borne in dichasial cymules on ultimate branches, central flower often sessile, lateral ones on pedicels to $4 \mathrm{~mm}$ long, hypanthium green when fresh, $1-1.8 \times 1.2-1.6$ $\mathrm{mm}$, broadly obovoid or obconical, tuberculate, calyx tube $0.2-0.4 \mathrm{~mm}$ long, glabrous externally and internally, calyx lobes $4(-5), 0.2-0.5 \mathrm{~mm}$ long, triangular, glabrous; corolla in bud 4-angular, apex obtuse, slightly or not depressed, at anthesis shortly hypocrateriform, when fresh with white lobes and green tube, tube 1.8-2.2 $\times 1-1.3$ $\mathrm{mm}$ medially, externally and internally glabrous, lobes 4 , triangular-ovate, $1.5-2 \times 1.3-$ $1.6 \mathrm{~mm}$, apex with a small incurved appendage, externally papillose, internally rugulose; anthers 4, 0.7-1.4 mm long, ellipsoid, apiculate, bilobed basally, sessile, attached below top of tube, tips exserted; style $1.5 \mathrm{~mm}$ long, stigma lobes $0.5 \mathrm{~mm}$ long, included in tube. Capsules $2 / 3$ inferior, broadly obovoid to subglobose, $4-5 \times 3.5-4 \mathrm{~mm}$ in diam., apex (beak portion above the calyx) rounded to conical, glabrous, dark brown when fresh, vascular bundles becoming visible with age, loculicidal, apex splitting into 4 segments. Seeds c. 200 , dull brown, $0.5-0.6 \times 0.35-0.4 \mathrm{~mm}$, irregularly ovoid to ellipsoid, laterally compressed, laterally cuneate with a marginal punctiform hilum, the testa irregularly reticulate with areoles enclosing granulate-verrucose mounds.

Distribution. This new species is known only from Ua Huka, Marquesas Islands, where it is apparently restricted to the Hokatu cliff zone above Hane village.

Ecology. Rare and localized, this new species occurs in mixed wet shrubland and herbland growing on basalt cliffs and rock outcrops above wet forest of Hibiscus tiliaceus L., Pandanus tectorius Parkinson, and Freycinetia impavida (Gaudich. ex Hombr.) B.C. Stone. Other associates include species of Bidens, Boehmeria, Maytenus, Peperomia, Alyxia, Morinda, Phyllanthus, Miscanthus, Macropiper, Xylosma, and diverse pteridophytes. It was collected in flower in December and June (in bud), and in fruit in June and December (old fruit with a few seeds). 


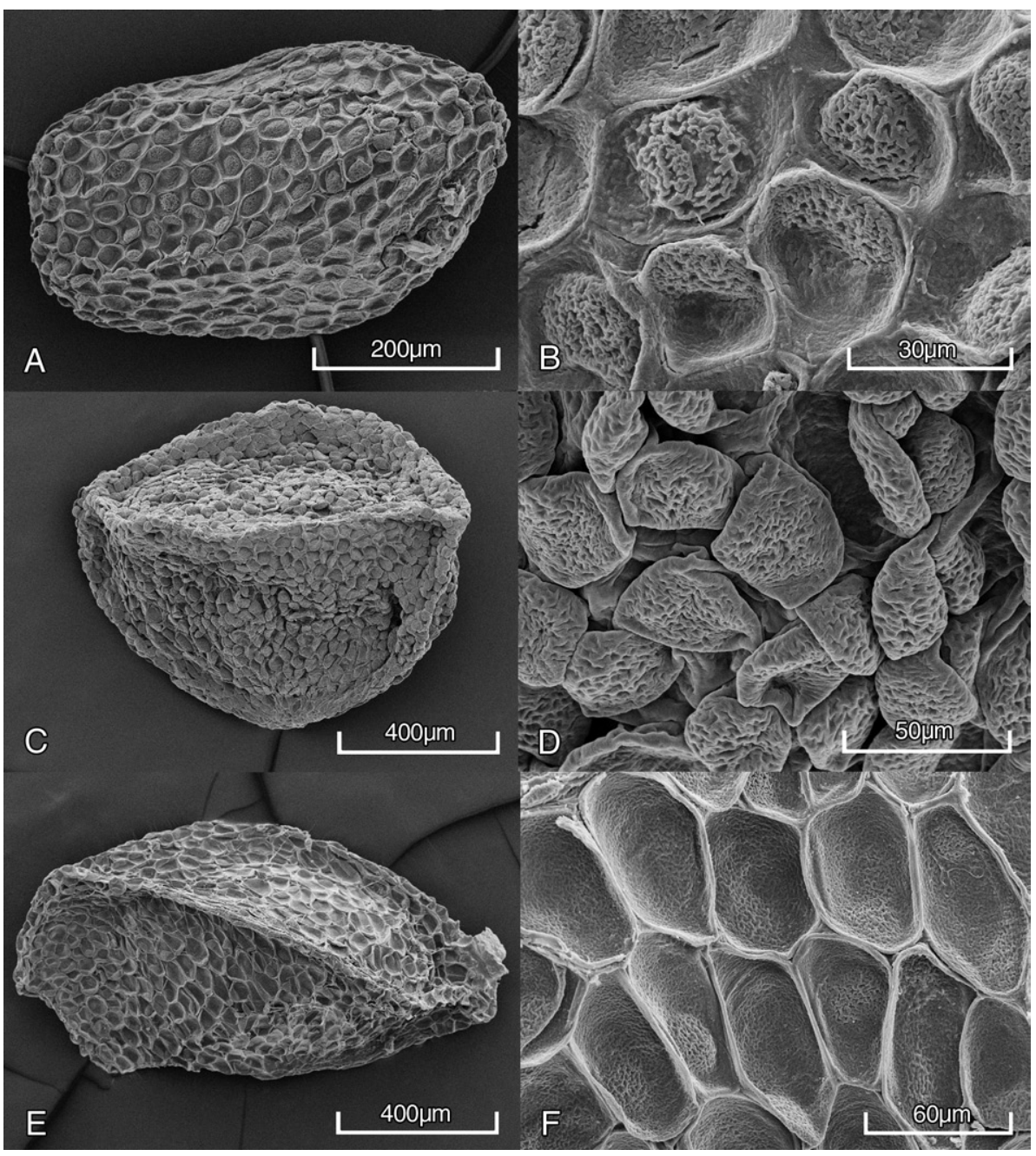

Figure 2. Seeds of three Marquesan Kadua species, whole seed and surface detail A, B Kadua lichtlei, Wood 10514 (PTBG) C, D Kadua nukuhivensis C Perlman 15029 (PTBG) D Perlman 15054 (PTBG) E, F Kadua tahuatensis Perlman 16020 (PTBG).

Etymology. We are pleased to name this new species in honor of Mr. Léon Lichtle, Mayor of Ua Huka, for his generous help and logistic support when we conducted field work on the island and also in recognition of his strong support for conserving the island's native flora and fauna.

Conservation status. The area of occupancy (distribution) for the species was calculated using herbarium collection data and field observations, and the conservation status is proposed following the IUCN Red List Category criteria (IUCN 2001). IUCN Red List Category: Critically Endangered (CR): B2a, B2b i-iii; D: B2: total area of occupancy less than $10 \mathrm{~km}^{2}\left(\mathrm{ca} .5 \mathrm{~km}^{2}\right)$. B2a, a single population known; b (i-iii), habitat continuing decline inferred. The suitable habitat for Kadua lichtlei on 
Ua Huka (ca. $83 \mathrm{~km}^{2}$ ) is indicated as an endangered environment, threatened feral animals and invasive plants, reducing the extent of the forest. Estimated population size is about 30 individuals known only from the type locality (Wood \& Meyer 10514). Threats include invasion by weeds including Psidium guajava L. and Ageratum conyzoides L., browsing by goats, and landslides. Several plants are in cultivation at the National Tropical Botanical Garden grown from seed (NTBG accession no. 040036, ex Wood 10514).

Specimens examined. Marquesas Islands: Ua Huka: Hane valley, ridge and cliffs above tiki marae, back of valley on west side, $8^{\circ} 54.48^{\prime} \mathrm{S}, 138^{\circ} 3.54^{\prime} \mathrm{W}, 518 \mathrm{~m}$, 12 Jun 2004, Perlman et al. 19007 (BISH, P, PAP, PTBG, US); Hane/Hokatu cliff zone, 520m, 11 December 2003, Wood \& Meyer 10514 (BISH, P, PAP, PTBG, US), 550m, 14 December 2003, Wood \& Meyer 10544 (PTBG, US), 10547 (PTBG, US), 12 June 2004, 854.72'S, 139 `31.60'W, 520 m, Wood et al. 10737 (PTBG), 19738 (PTBG, US).

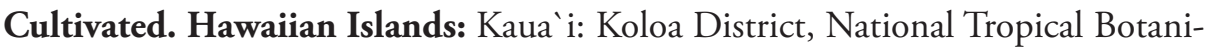
cal Garden, horticulture center nursery, 5 October 2005, Lorence 9476 (PTBG, US).

Discussion. Within the Marquesan clade Kadua lichtlei differs markedly from the other three species by a number of characters, notably its broadly elliptic to broadly ovate or subcircular leaf blades, much smaller and more numerous flowers (80-300 per inflorescence), and smaller capsules. In addition, seeds of $K$. nukubivensis and $K$. tahuatensis (those of $K$. lucei were not available) are more sharply angulate with well defined marginal ridges. Seed morphology has proven useful in the infrageneric classification of Kadua (Terrell et al. 2005). Seeds of $K$. lichtlei are laterally compressed and laterally cuneate with a marginal punctiform hilum, ovoid to ellipsoid, and irregularly angulate with an irregularly reticulate testa with areoles enclosing reticulate-verrucose mounds (Fig. 1G, 2A,B). Its seed morphology suggests an affinity to species of the Hawaiian Kadua sect. Kadua (Terrell et al. 2005). However, we here place K. lichtlei in section Austrogouldia, partly based on the fact that the intra-areolar seed surface has reticulate verrucose sculpturing and is somewhat different from that in sect. Kadua. Seeds of species examined so far in this section (K. nukuhivensis and K. tahuatensis) link section Austrogouldia to the Hawaiian sect. Kadua.

\section{Kadua lucei (Lorence \& J.Florence) W.L.Wagner \& Lorence, Syst. Bot. 30:832 2005.}

http://species-id.net/wiki/Kadua_lucei

Basionym. Hedyotis lucei Lorence \& J. Florence (Adansonia, sér. 3, 22: 225, 2000).

Type. Marquesas Islands: Fatu Hiva: au pied de la crête à Touaouoho, env. 1000 m, 3 Aôut 1999, J.-P. Luce s.n. (Holotype P!)

Description. Glabrous shrubs 1.5-2 m tall, leafy twigs 4-6 $\mathrm{mm}$ in diam., internodes compressed, bark brown, smooth to striate or rugulose. Leaves of a pair equal to subequal, blade elliptic to obovate-elliptic, (5.3-)10-14.5 $\times(3.3-) 7-10 \mathrm{~cm}$, dis- 


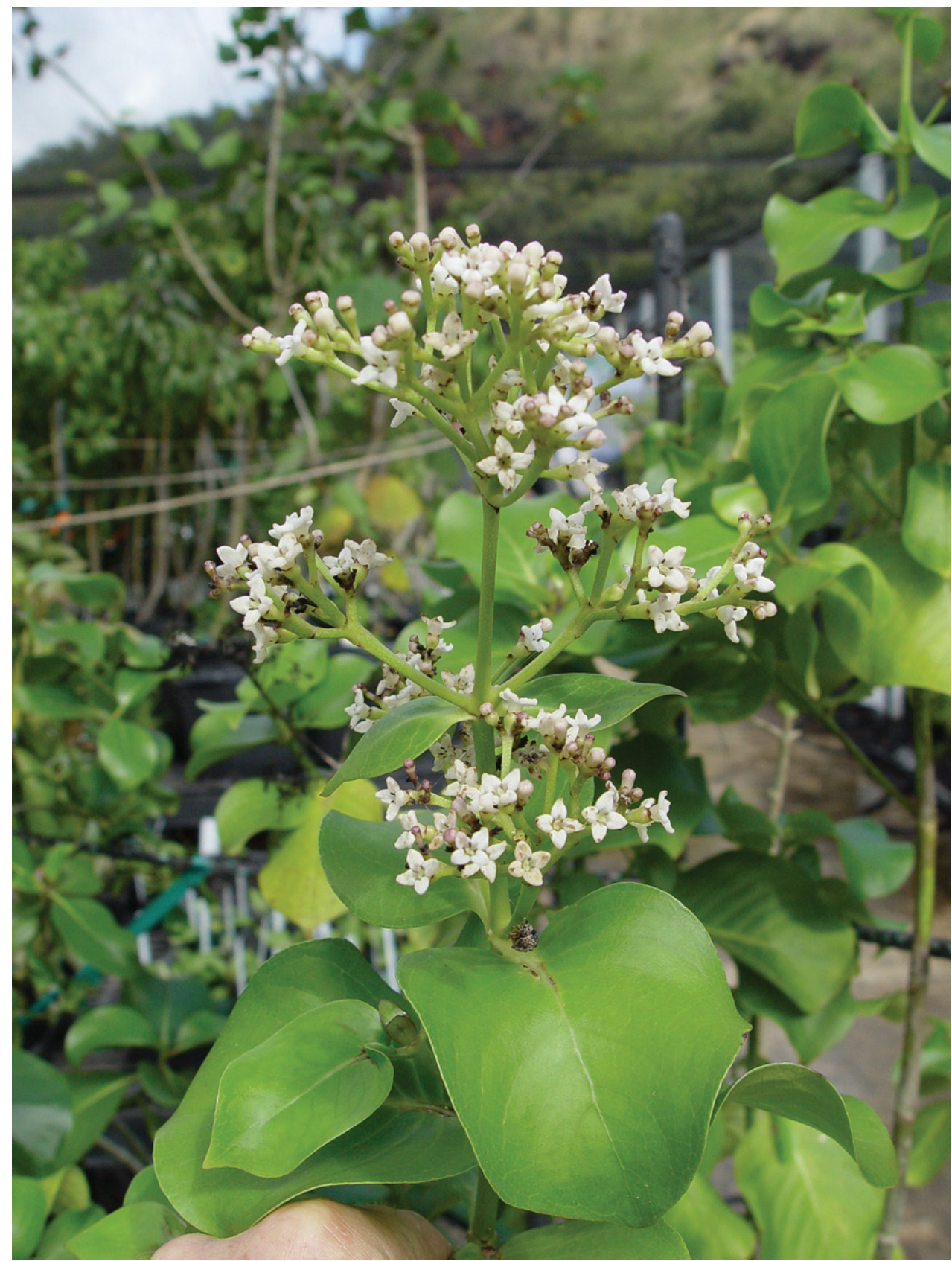

Figure 3. Kadua lichtlei, flowering plant growing the National Tropical Botanical Garden nursery, 5 Oct. 2005, Lorence 9476 (PTBG).

colorous, chartaceous to subcoriaceous, base acute to obtuse or rounded, apex acute to obtuse or rounded, often abruptly short acuminate, margin entire, weakly revolute; secondary veins $8-10$ pairs, loosely brochidodromous, secondary veins prominulous 
on both surfaces, tertiary veins slightly prominulous below; petioles purple when fresh, $2-4 \times 2-5 \mathrm{~mm}$, stout, adaxially flattened and slightly winged; stipules inter- and intrapetiolar, apex shortly cuspidate, sheath semicircular, $3 \times 4-7 \mathrm{~mm}$, fused with the adaxial petiole bases. Inflorescences (only seen with old flowers and young fruits) terminal, corymbiform cymose, $8-9 \times 6 \mathrm{~cm}$, peduncle $35 \mathrm{~mm}$ long, $2.5-3 \mathrm{~mm}$ in diameter, compressed, primary axis $2.5-3 \mathrm{~cm} \times 2-2.5 \mathrm{~mm}$ with two pair of secondary branches, the lower pair often branching once again, the upper pair unbranched, the ultimate branches each bearing 2-3 flowers, lower bracts foliaceous, suborbicular, $15 \mathrm{~mm}$ in diam. Flowers glabrous, about 30 per inflorescence, bracts broadly triangular, scarious, $1 \times 1.5 \mathrm{~mm}$, pedicels stout, $2-3 \times 0.5-1 \mathrm{~mm}$; hypanthium obconical, $2-3 \mathrm{~mm}$ long, calyx limb cupuliform, $2-3 \mathrm{~mm}$ long, calyx lobes 4 , broadly triangular, $0.5-0.7$ $\times 1.5 \mathrm{~mm}$; corolla fleshy, white when fresh, buds not seen, at anthesis salverform, tube purple tinged when fresh, 22-26 mm long, $1.7-2 \mathrm{~mm}$ wide medially, lobes 4 , linear to oblong, recurved, $8-10 \times 1.5-2 \mathrm{~mm}$, apex with a hook-like appendage $0.5-1 \mathrm{~mm}$ long; flowers possibly dimorphic; stamens included, anthers linear, 3-3.5 × 0.3-0.4 $\mathrm{mm}$, connective attached $2 \mathrm{~mm}$ from apex of tube; style included, $20 \mathrm{~mm}$ long, two stigmatic lobes linear, $2.5 \mathrm{~mm}$ long. Fruits on stout pedicels 5-7 mm long, capsules turbinate to obovoid-turbinate, old capsules $7-8 \times 6 \mathrm{~mm}$, consisting of network of persistent vascular bundles enclosing endocarp, apex (beak portion above the calyx) 1-1.5 mm long. Seeds not seen.

Distribution. Marquesas Islands, Fatu Hiva where known only from a single small population on the summit ridge between Tekou and Touaouoho peaks.

Ecology. This new species was collected at $915-1000 \mathrm{~m}$ elevation on a steep, precipitous ridge crest in wet shrubland with species of Alsophila, Freycinetia, and Histiopteris.

Etymology. The specific epithet honors its discoverer and first collector, Mr. JeanPierre Luce, an amateur naturalist, in recognition of his efforts to explore the most rugged mountainous zones of the Marquesas and thus increase our knowledge of their flora and vegetation.

Conservation status. The suitable habitat for Kadua lucei on Fatu Hiva (ca. 85 $\mathrm{km}^{2}$ ) is indicated as an endangered environment, threatened by feral animals and invasive plants, reducing the extent of the forest. Estimated population size is about 3-4 individuals. Following the criteria and categories of IUCN (2001) Kadua lucei is assigned a preliminary Red List status of Critically Endangered (CR): B2a, B2b (i-iii); D: B2: total area of occupancy less than $10 \mathrm{~km}^{2}\left(\mathrm{ca} .5 \mathrm{~km}^{2}\right)$. B2a, a single population known; $b$ (i-iii), habitat continuing decline inferred. D, population estimated to number fewer than 250 individuals.

Specimen examined. Marquesas Islands: Fatu Hiva: sous la crête entre Tekou et Touaouoho, 915 m, 15 février 2000 (st), J.-Y. Meyer \& J.-P. Luce 835 (PAP, PTBG).

Discussion. This species is apparently related to Kadua tahuatensis from which it differs by its larger inflorescence reaching $8-9 \mathrm{~cm}$ long and $6 \mathrm{~cm}$ wide, more numerous flowers, about 30 per inflorescence, and larger white corollas with a longer purple- 
tinged tube 22-26 mm long. Although mature fruits of $K$. lucei are not known, old fruits are smaller than those of $K$. nukuhivensis and $K$. tahuatensis.

\section{Kadua nukubivensis (Lorence \& J.Florence) W.L.Wagner \& Lorence, Syst. Bot. 30 : 832, 2005.}

Fig. 2C, D.

http://species-id.net/wiki/Kadua_nukuhivensis

Basionym. Hedyotis nukuhivensis J.Florence \& Lorence (Adansonia sér. 3, 22: 224, 2000).

Type. Marquesas Islands: Nuku Hiva: route Toovii-Terre Déserte, $5 \mathrm{~km}$ après le col, 852'S-140¹0’W, 1020 m, 5 juin 1984, J. Florence 6914 (Holotype P!; Isotypes BISH!, P!, PAP!, PTBG!, US!).

Description. Glabrous shrubs or small trees $2.5-6 \mathrm{~m}$ tall, trunk to $20 \mathrm{~cm}$ in diam., leafy twigs cylindrical, 7-9 $\mathrm{mm}$ in diam., internodes compressed, bark grayish- to blackish-brown. Leaves of a pair equal to sometimes unequal, blade obovate to obovate elliptic or oblong, $8-18 \times 6-10.5 \mathrm{~cm}$, chartaceous to subcoriaceous, drying brown or blackish-brown, base cuneate, decurrent, apex obtuse to rounded, secondary veins 7-9 pairs, loosely brochidodromous, prominulous above, tertiary veins slightly prominulous, higher order venation obscure, midrib sulcate above, rounded below, margin entire, plane to slightly revolute; petioles $8-13 \times 2-3 \mathrm{~mm}$ in diam., sulcate; stipules inter- and intrapetiolar, sheath truncate, cupuliform, 2.5-3 $\times 5-6 \mathrm{~mm}$, caducous but becoming thickened and horseshoe-like on adaxial surface of petioles. Inflorescences terminal and rarely also axillary in upper leaf axils, cymose, corymbiform, $7-13 \mathrm{~cm}$ long including corollas, on a stout, compressed peduncle $3-6 \mathrm{~cm}$ long or sessile with a pair of basal branches, often subtended by a pair of reduced subsessile leaves, bracts foliaceous, 1.5-3 cm long, caducous. Flowers 12-30, possibly dimorphic, fragrant when fresh, subtended by caducous triangular bracts c. $1 \mathrm{~mm}$ long, hypanthium obconical, $3 \mathrm{~mm}$ long, calyx limb cupuliform, $2 \mathrm{~mm}$ long, calyx lobes broadly triangular, $0.3-0.5$ mm long; corolla fleshy, white or pinkish white when fresh, apex flat to slightly depressed in bud, at anthesis salverform, tube $26-28 \times 2 \mathrm{~mm}$ in diam. distally, lobes 4 , linear-oblong, recurved, 10-15 × 3-5 mm, apex with a recurved hook-like appendage; stamens with anther tips exserted for $1.5 \mathrm{~mm}$, mucronulate, linear, 3-4 $4 \mathrm{~mm}$, attached 1.5-2 mm below apex of tube; style 17-19 $\mathrm{mm}$ long, included, stigmatic lobes 2, adnate, $3 \mathrm{~mm}$ long. Capsules on stout pedicels to $6 \mathrm{~mm}$ long, turbinate to obpyriform, 15-25 × 7-14 mm, strongly compressed, bisulcate, strongly 8-ribbed, 2/3 inferior, apex (beak portion above the calyx) obtuse, 5-6 mm long, smooth, dehiscence loculicidal then septicidal, old capsules disintegrating leaving network of vascular bundles enclosing the persistent endocarp. Seeds $1-1.3 \times 0.5-0.9 \mathrm{~mm}$, irregularly angulate to broadly ellipsoid, trigonous, margins thin, testa dull, dark brown, surface finely papillose. 
Distribution. Marquesas Islands, Nuku Hiva, where known only from the island's central mountain crest, on the leeward side of the Terre Déserte in the upper Tapuaehu Valley, between 1000 and 1065 m elevation.

Ecology. This species occurs in wet forest with species of Hernandia, Ilex, Metrosideros, and Weinmannia in the canopy and the understory with species of Cyrtandra, Melicope, and Psychotria. Numerous pteridophytes occur terrestrially and as epiphytes. Kadua nukuhivensis also occurs in shrubland on ridge crests with species of Alsophila, Bidens, Dicranopteris, Elaphoglossum, Freycinetia, Pennisetum, and Styphelia.

Etymology. The specific epithet refers to the only known island of occurrence for this species.

Conservation status. The suitable habitat for Kadua nukuhivensis on Nuku Hiva (c. $340 \mathrm{~km}^{2}$ ) is indicated as an endangered environment, threatened by human activity (deforestation and fire), feral animals, and invasive plants, thus reducing the extent of the forest. Based on the IUCN criteria and categories this species is assigned a preliminary Red List status of Endangered (EN): B1, B2b (i-iii): B1 extent of occurrence $<5,000 \mathrm{~km}^{2}$; B2: total area of occupancy less than $500 \mathrm{~km}^{2}$ (c. $75 \mathrm{~km}^{2}$ ); B2b (i-iii), habitat continuing decline inferred in (i) extent of occurrence, (ii) areas of occupancy, and area, (iii) extent and/or quality of habitat. This status is a revision from VU originally suggested by Florence and Lorence (2000).

Specimens examined. Marquesas Islands: Nuku Hiva: Route Toovii-Terre Déserte, haute Tapuaehu, 852'S-140¹1'W, 1020 m, 14 fév 1986, Florence 7545 (BISH, P, PAP, US); off the old Airport road west of the summit crest of Peak \#1227 $\mathrm{m}$, drainages of Tapueahu Valley, 0.75 miles south of Airport Road, bottom of valley, 3340 ft., 24 sep 1995, Perlman 15054 (AD, BISH, MO, P, PAP, PTBG (2), US); Ooumu area (sic), top of Tapueahu off new Hwy, 851'53"S-140¹0'63”W, $3500 \mathrm{ft}$, 23 jun 1997, Wood, Meyer \& Luce 6337 (BISH, P, PAP, PTBG, US).

Discussion. Kadua nukuhivensis resembles $K$. tahuatensis, and molecular evidence places these two as sister species in the same clade within the larger clade of Hawaiian and French Polynesian species (Motley 2003)

\section{Kadua tahuatensis (Lorence \& J.Florence) W. L.Wagner \& Lorence (Syst. Bot. 30 : 832, 2005).}

http://species-id.net/wiki/Kadua_tahuatensis

Fig. 2E, F.

Basionym. Hedyotis tahuatensis Lorence \& J. Florence (Adansonia sér. 3, 22: 227. 2000).

Type. Marquesas Islands: Tahuata: ridge between Amatea and Haaoiputeomo, southfacing slope, $2580 \mathrm{ft}$. [780 m] elevation, 19 july 1997, S. P. Perlman 16020 (Holotype: PTBG-30160!; Isotypes: BISH!, MO!, P!, PAP!, US!).

Glabrous shrubs to $2 \mathrm{~m}$ tall, leafy twigs $4-6 \mathrm{~mm}$ in diam., internodes strongly compressed, bark pale brown, smooth to striate. Leaves of a pair equal to subequal, blade 
elliptic to obovate-elliptic, $4.2-15 \times 2-8 \mathrm{~cm}$, discolorus, chartaceous to subcoriaceous, base acute to cuneate or narrowly cuneate, apex obtuse to rounded, tip sometimes abruptly short acuminate, secondary veins (5-) 6-9 pairs, weakly brochidodromous, secondary and tertiary veins prominulous on both surfaces, higher order venation obscure, margin thickened, plane; petiole stout, $2-5 \times 2-3 \mathrm{~mm}$, adaxially sulcate; stipules inter- and intrapetiolar, sheath cupuliform, truncate, $3 \times 5-6 \mathrm{~mm}$, persistent, fused with adaxial petiole surfaces and becoming thickened and horseshoe-like. Inflorescences terminal, thyrsiform cymose, 23-25-flowered, 5-6 × 4.5-6 cm (including corollas), on peduncle to $2 \mathrm{~cm}$ long, $1.5-2 \mathrm{~mm}$ in diam., flattened, primary axis $15 \times 1.5-2 \mathrm{~mm}$ with 2 pairs of lateral branches, the basal one often branching once, lower bracts foliaceous, ovate, $1.2-2 \times 1-1.5 \mathrm{~cm}$, upper branch pair unbranched, ultimate branches ending in 2-3 flowers. Flowers glabrous, on stout pedicels $2-3 \times 0.8-1.4$, compressed, bracts scarious, ovate-trangular, $1 \times 1 \mathrm{~mm}$, hypanthium obconical, $3-4 \times 1.5-2 \mathrm{~mm}$, calyx limb campanulate, $2-3 \times 4-5 \mathrm{~mm}$, lobes ovate-triangular, $1.5-2 \times 2-2.5 \mathrm{~mm}$; corolla fleshy, pale green when fresh, lobes with dark purple margins, in bud fusiform with non-depressed apex, at anthesis salverform, tube 13-16 × 1.5-2 mm in diam. medially, lobes 4 , linear-oblong, recurved, $8-10 \times 1.5-2 \mathrm{~mm}$, apex with a hooked appendage 1 $\mathrm{mm}$ long; flowers possibly dimorphic, stamens exserted for $1.5-2 \mathrm{~mm}$, linear, 3-3.5 $\times$ $0.5-0.6 \mathrm{~mm}$, attached $1-1.5 \mathrm{~mm}$ below apex of tube, apex slightly mucronulate; style included, 11-12 mm long including 2 coalescent stigmatic lobes $2.5 \mathrm{~mm}$ long. Fruits on stout pedicels 3-8 mm long; capsule tubinate to obovoid-turbinate, $12-20 \times 6-8$ $\mathrm{mm}$, sub-quadrangular, $2 / 3$ inferior, apex with short beak portion 5-6 $\mathrm{mm}$ long above the calyx, dehiscence at first loculicidal then septicidal, old capsules disintegrating into network of vascular bundles enclosing persistent, bisulcate endocarp. Seeds irregularly trigonous or angulate, $0.9-1.2 \mathrm{~mm}$ long and wide, margins with narrow wing 0.1-0.3 $\mathrm{mm}$ wide, testa finely reticulate.

Etymology. The specific epithet refers to the only known island of occurrence for this species.

Distribution. Marquesas Islands, Tahuata, known only from the island's summit crest and high southeastern slopes between 780 and 835 m elevation.

Ecology. Occurs in wet montane forest and shrubland with species of Alsophila, Cheirodendron, Crossostylis, Hibiscus, Metrosideros, Reynoldsia, Weinmannia, and pteridophytes including Asplenium, Blechnum, Elaphoglossum, Lycopodiella and Nephrolepis,

Conservation status. The suitable habitat for Kadua tahuatensis on Tahuata (c. 61 $\left.\mathrm{km}^{2}\right)$ is indicated as an endangered environment, threatened by feral animals and invasive plants, reducing the extent of the forest. This species is extremely rare, with only five plants known from two localities. Following the criteria and categories of IUCN (2001) it is assigned a preliminary status of Critically Endangered (CR): B2a, B2b (i-iii); D: B2: total area of occupancy less than $10 \mathrm{~km}^{2}$ (ca. $5 \mathrm{~km}^{2}$ ). B2a, a single population known; b (i-iii), habitat continuing decline inferred; $\mathrm{D}$, population estimated to number fewer than 250 individuals. 
Specimen examined. Marquesas Islands: Tahuata: ridge between Amatea and Haaoiputeomo, southeast-facing slopes over Hanatetena village, $2740 \mathrm{ft}$. (835 m) elevation, 11 July 1997, Perlman 15954 (P, PAP, PTBG, US).

Discussion. Morphologically Kadua tahuatensis closely resembles $K$. nukuhivensis, and molecular evidence places these two as sister species in the same clade as $K$. rapensis F. Br. and K. romanzoffeensis Cham. \& Schltdl. within the larger clade of Hawaiian and French Polynesian species (Motley 2003).

\section{Acknowledgments}

This study was greatly facilitated by useful discussions, field observations, photos, and specimens provided by Dr. Jean-Yves Meyer (Délégation à la Recherche, Polynésie française), Ken Wood and Steve Perlman (National Tropical Botanical Garden), and Jacques Florence (IRD, Paris). Important observations and collections resulted from fieldwork carried out during trips in 2003 and 2004 as part of the "Vascular Flora of the Marquesas Islands" project, which was supported by a generous project donation. We are grateful to the Délégation à la Recherche (Papeete, Tahiti), the Musée de Tahiti et des Iles, Mr. Léon Lichtle and the Service du Développement Rural for logistic support on Ua Huka, the Délégation for permission to collect in the Marquesas, and the Délégation and the Haut-Commissariat de la République en Polynésie française for permission to conduct research. The illustration was skillfully drawn by Alice Tangerini (US). We thank Marjorie Knowles and Harold Robinson of the Smithsonian Institution for preparing the SEM seed images. We are grateful to Harold Robinson and Charlotte Taylor for reviewing the manuscript. The contribution by WLW to this study was partially supported by the Smithsonian Research Opportunities Fund and while appointed as McBryde Chair at the National Tropical Botanical Garden.

\section{References}

Brown FBH (1935) Flora of Southeastern Polynesia. Bernice P. Bishop Museum Bulletin 130: $1-386$.

Church, SA (2003) Molecular phylogenetics of Houstonia (Rubiaceae): descending aneuploidy and breeding system evolution in the radiation of the lineage across North America. Molecular Phylogenetics and Evolution 27: 223-238. doi:10.1016/S1055-7903(02)00446-3

Florence J, Lorence DH (2000) Sertum polynesicum VI. Rubiaceae nouvelles des îles Marquises (Polynésie française) 2. Le genre Hedyotis. Adansonia, sér. 3, 22: 223-230.

Fosberg FR (1943) The Polynesian species of Hedyotis (Rubiaceae). Bernice P. Bishop Museum Bulletin 174: 1-102.

Groeninckx I, Dessein S, Ochoterena H, Persson C, Motley TJ, Kårehed J, Bremer B, Huysmans S, Smets E (2009) Phylogeny of the herbaceous Tribe Spermacoceae (Rubiaceae) 
based on plastid DNA data. Annals of the Missouri Botanical Garden 96: 109-132. doi:10.3417/2006201

IUCN (2001) IUCN Red List categories (version 3.1). IUCN Species Survival Commission, Gland, Switzerland.

Kårehed J, Groeninckx I, Dessein S, Motley TJ, Bremer B (2008) The phylogenetic unity of chloroplast and nuclear DNA markers and the phylogeny of the Rubiaceae tribe Spermacoceae. Molecular Phylogenetics and Evolution 49: 843-866. doi:10.1016/j.ympev.2008.09.025

Lorence DH (Ed) (1997) Botanical Results of the 1988 Fatu Hiva Expedition to the Marquesas Islands. Allertonia 7: 221-306.

Lorence DH, Wagner WL, Laidlaw WG (2010) Kadua haupuensis (Rubiaceae: Spermacoceae), a new endemic species from Kauai i, Hawaiian Islands. Brittonia 61: 137-144. doi:10.1007/s12228-009-9103-y

Motley T J (2003) Phylogeny of Hawaiian and Pacific Hedyotis (Rubiaceae): fruit evolution and the implications for conservation and genomics. Abstracts of Annual Meeting, Mobile, Alabama, Botany 2003: 88-89. http://www.2003.botanyconference.org/engine/search/detail.php?aid377

Terrell EE, Robinson H (2003) Survey of Asian and Pacific species of Hedyotis and Exallage (Rubiaceae) with nomenclatural notes on Hedyotis types. Taxon 52: 775-782. doi:10.2307/3647351

Terrell EE, Robinson HE, Wagner WL, Lorence DH (2005) Resurrection of the genus Kadua for Hawaiian Hedyotidinae (Rubiaceae), with emphasis on seed and capsule characters and notes on South Pacific species. Systematic Botany 30: 818-833. doi:10.1600/036364405775097716

Wagner WL, Lorence DH (1997) Studies of Marquesan vascular plants: Introduction. Allertonia 7: 221-225.

Wagner WL, Herbst DR, Sohmer SH (1990) Manual of the Flowering Plants of Hawai'i. University of Hawaii Press and Bishop Museum Press. 